\title{
СТИЛЬОВІ ДОМІНАНТИ РАННЬОЇ ПРОЗИ Ю. ЯНОВСЬКОГО
}

Савченко 3. В.

\section{ВСТУП}

Юрій Яновський належав до плеяди тієї талановитої української молоді, яку на початку XX століття захопив стрімкий розмах національного відродження. Реагуючи на запити часу, він разом із численними однодумцями став дієвим творцем цілковито нового стилю в українській літературі 20 -х років, що згодом дістав назву «активний романтизм». Однак творчу долю цього, без сумніву, видатного письменника нелегко порівнювати 3 кимось із митців буремної доби літературних перетворень, бо, володіючи надзвичайним талантом, він був покликаний досягти найбільших висот художнього слова, та, на жаль, зупинився на підступах до них.

Глибока закоханість у художнє слово з молодих років володіла душею Ю. Яновського, надихаючи юнака на натхненно-патетичні рядки перших поезій. Згодом це захоплення переросло в мовну легкість і прозорість образів, у романтичне оспівування вічної молодості, кохання та людської гідності, що й залишилось визначальним у мистецькій діяльності письменника загалом. Життєвий досвід, грунтовне знайомство 3 літературною атмосферою західноєвропейського світу, із творчістю англійських та американських неоромантиків поступово вдосконалювали творчу манеру Ю. Яновського, збагачували його романтичну палітру мотивами зв'язку минувшини і сьогодення рідного краю, одвічної боротьби українського народу за волю, його трагічних поразок та повсякчасної героїки. Молодий письменник-початківець мав чіткі життєві орієнтири, вірив у власні сили і в обов'язкову перемогу того літературного напряму, під прапори якого він став. Як наслідок, рання творчість митця вражає авторською вірою в людину, яка наперекір шаленому опору зовнішнього світу впевнено крокує вперед як переможець.

Вітаїстичний дух водив пером Ю. Яновського під час написання ранніх оповідань та перших значних романів. Однак, на превеликий жаль, досягши апогею розквіту свого таланту, письменник ураз опинився перед уламками великого натхнення. Йому довелося на собі випробувати брутальні методи впливу радянської ідеології. У змаганні 3 нею Ю. Яновському випаде пережити терор 1933-1938 років і ввійти до групи деякою мірою упокорених діячів української культури. 
Не у змозі знову налагодити чутливі поетичні струни, що починали бриніти вкрай фальшиво, він писатиме «Київські оповідання», «Нову книгу» й інші твори, суголосні вимогам офіційної критики. Це буде повільне конання майстра під нещадним тиском приписів соцреалізму.

Сьогодні побутує думка, що останнім романом Ю. Яновського, який остаточно спотворити не вдалося, стали його «Вершники». Цей же твір можемо вважати першим сигналом про те, що над талантом письменника, як i над усією молодою української літературою, чиниться наруга. Вистояти в напруженій боротьбі митець не зміг смертоносний для проявів авторської індивідуальності моностиль сталінської диктатури зломив його «романтичну шпагу». Але ті твори, що народжувались за покликом серця, увійшли в історію національної культури й залишаються яскравим свідченням стильового розмаїття української прози 20-30-х років XX століття.

\section{1. Специфіка художнього осмислення українських реалій у «малій» прозі Ю. Яновського}

Прагнення відійти від усталених мистецьких традицій, сказати власне оригінальне слово в літературі знайшло своє втілення вже в перших збірках оповідань Ю. Яновського «Мамутові бивні» та «Кров землі». Пульсація життя, буяння молодості стали головною ознакою, що визначала новаторство автора на рівні змістового наповнення книг. Тематичний діапазон ранніх оповідань охоплює період перших пореволюційних років в Україні. Героїка громадянської війни, боротьба за утвердження високих ідеалів, овіяні романтикою активного творення, - ось той смисловий стрижень, що становив собою антитезу старому світові й наочно відтворював процес формування нової художньої парадигми й нового літературного змісту. У кращих творах Ю. Яновського цей зміст був справді новаторським і перебував у тісному зв'язку з романтичними уявленнями письменника про епоху суспільних перетворень.

Самобутність оповідань збірок «Мамутові бивні» та «Кров землі» забезпечувалась передусім неординарністю індивідуального стилю митця. Його героями переважно ставали молоді люди, віддані власним ідеалам і здатні захищати їх зі зброєю в руках. Показовим $є$ те, що на перший план письменник виводить уже сформовану особистість. Його не цікавить еволюція характеру героя. Натомість Ю. Яновський застосовує романтичний прийом випробовування людини в екстремальних умовах, у кульмінаційний момент ії життя. Зокрема, у такій ситуації опиняються Рубан - герой дилогії «Роман Ма» та «Туз і перстень», Кіхана в «Байгороді», герой оповідання «Історія попільниці». Письменник накреслює основний конфлікт, під час 
вирішення якого й виявляються найбільш показові риси характеру персонажів.

Для досягнення бажаного результату автор активно використовує техніку контрасту, що на тематичному рівні зосереджується на протиставленні понять «кохання і смерть», «кохання й обов'язок». Зокрема, зіткнувшись із фактом зради коханої («Історія попільниці», «Роман Ма»), герої, позбавлені можливості об’єднати в гармонійне ціле власні почуття й покликання борця та громадянина, мають неодмінно зробити внутрішній вибір. Зазвичай Ю. Яновський психологічно напружує момент змагання двох пристрастей, однак, на наш погляд, цей психологізм одноплановий, він не має суттєвого впливу на вирішення дилеми. Вочевидь письменник послідовно віддає перевагу поняттю «обов'язок», про що свідчить загибель від руки коханого героїнь-зрадниць. Уважаємо, що якраз завдяки такому стильовому прийому кохання в рефлекторному світлі смерті отримує фатальне тло, а смерть у світлі любові, навпаки, яскравіше підкреслює ту цінність людського життя, що становить суть краси трагічного.

Таке протиставлення, але дещо в іншому аспекті, можемо спостерігати і в повісті «Байгород», де автор випробовує вісімнадцятирічного юнака Кіхану одразу двома способами: надзвичайним коханням до дівчини Лізи та боротьбою проти анархізму, щоби наприкінці твору об’єднати їх в один - випробування життям. Кіхана теж обирає між почуттям і обов'язком, та, на відміну від попередніх оповідань, цей вибір не настільки стихійний і фатальний. Навпаки, любов і обов'язок у «Байгороді» спочатку поєднуються, створюють атмосферу піднесеної краси людського існування: «Ліза стояла 3 Кіханою під будинком, торкаючись плечем його грудей $<\ldots>$ Хвилини такого стояння, коли раптом може обсипати кулями кулемет, - ніколи не загубляться і стоятимуть завше понад усім в житті. I стара людина опустить руки за роботою, згадавши цей пафос боротьби й мовчазної

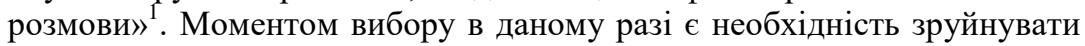
гармонію в ім'я обов'язку: «Тепер хай суворий меч романтики розлучить наших героїв, не давши їм надії, а давши скромну мужність все перетерпіти» ${ }^{2}$. У підсумку смерть головного героя повісті сприймається як логічне завершення емоційно виснажливого випробовування. Утвердити перемогу над ворогом ціною не лише кохання, а й життя, відкинувши водночас найменший натяк на песимізм та проспівавши у фіналі справжній гімн молодості, - прийом, який підтверджує активно романтичну орієнтованість повісті «Байгород».

\footnotetext{
${ }^{1}$ Яновський Ю. Твори : у 5-ти т. Київ : Дніпро, 1983. Т. 1. С. 103.

${ }^{2}$ Там само. С. 103.
} 
Ще одна колізія, яка цікавить Ю. Яновського на початкових етапах літературної діяльності, - повстанська стихія й особиста дисципліна, воля, що приборкує стихію, а також роль у цьому процесі сильної особистості. Вочевидь оповідання збірок «Мамутові бивні» та «Кров землі» несуть на собі відбиток складної «української» специфіки громадянської війни. Ї̈̈ характерними ознаками в авторській інтерпретації стали відсутність чіткої організації дій, отаманство, хиткість ідейних позицій, хронічна драма роз'єднаності. Таку стихію непросто скерувати в певне русло. Тому для виконання поставленого завдання письменник обирає людей вольових i сильних, які, переборюючи власну вольницю, виховують дисципліну серед інших («Роман Ма», «Туз і перстень»).

Наступною рисою дієворомантичного стилю Ю. Яновського $\epsilon$ характеристика персонажів через їхні вчинки (без посередництва традиційних монологів чи діалогів). Виводячи свого героя-борця з рамок статичності у сферу динамічного руху, митець ставить у центр оповіді дію. Його герої зазвичай натури неспокійні, енергійні, що зумовлюється законами романтичної логіки. У своєму жаданні нового життя, ідеалу, вони здатні на непередбачувані кроки, їхня поведінка цілком підпорядкована ідеям боротьби. Такий алгоритм побудови образу нагадує швидкоплинні замальовки, що, з одного боку, призводить до деякого схематизму, а з іншого - $є$ тим гармонійним поєднанням темпераменту та глибини переконань, що становить основу характеротворення персонажів.

Головним тембральним нервом притаманної письменнику оповідної манери стала відкрита присутність у ній авторського «я». Це стосується, зокрема, ставлення до героїв оповідань: авторська оцінка простежується крізь усі вчинки, навіть більше, іноді складається враження «театру маріонеток», тобто прямої залежності поведінки персонажів від волі прозаїка. За нашими спостереженнями, створенню такого ефекту сприяють відсутність біографічних відомостей про дійових осіб, їхніх внутрішніх монологів-роздумів, винятковість обставин, у яких герої змушені діяти, та відмова від пояснення причин вибору тієї чи іншої позиції. Такий принцип образотворення часом дещо знижує художній рівень «малої» прози Ю. Яновського, на чому наголошувала тогочасна критика (зокрема, Ф. Якубовський, Г. Майфет), вказуючи на відсутність глибокого психологічного аналізу, на певну плутаність у змалюванні героїчних постатей, намагання романтизувати і позитивне, і негативне тощо. Однак варто зважати на те, що ми маємо справу з першими оповіданнями та повістями письменника, який на той час, хоч і не завжди вирізнявся досконалістю творчого почерку, прагнув знайти свій індивідуальний шлях у мистецтві. 
Заперечення шаблонності в ранніх творах Ю. Яновського простежується не лише на рівні змісту, а й на рівні форми оповідань. Боячись банальностей сильніше, ніж карколомних композицій, несподіваних метафор i порівнянь, химерно-загадкових сюжетних ситуацій, письменник прагнув утвердити право митця на нетривіальність думки і способів іiі художнього вираження. Оповідання збірок «Мамутові бивні» та «Кров землі» мають здебільшого фрагментарну будову, що часто порушує хронологію оповіді. За допомогою засобів деструкції (наприклад, зміщення часових площин) Ю. Яновський робить спробу побачити в новому житті наслідки мрій і завоювань попередніх епох і поколінь. Звідси такі художні елементи, як нібито походження 3 гетьманського роду героїні оповідання «Історія попільниці» Оксани Полуботок або ж промовиста паралель між героєм «Байгорода» Кіханою та романтичним лицарем із роману М. Сервантеса. Такі зіставлення, з одного боку, надавали творам прозаїка екзотичності, а 3 іншого сприяли організації тексту таким способом, коли один фрагмент символічно унаочнював інші з метою створення об'ємного художнього образу без надмірної деталізації (на зразок бальзаківської).

Не менш характерною ознакою ранніх оповідань Ю. Яновського $\epsilon$ створення деякого дисонансу між напруженням дії i нарочитою врівноваженістю ii опису. Спокійний ритм стає найповільнішим у найбільш драматичному місці твору, що досягається шляхом використання ліричних відступів, нагромадженням образів, порівнянь тощо.

Поряд із прийомом зміщення часових площин письменник ускладнює композицію своїх оповідань шляхом використання загадок, несподіванок, колового обрамлення твору. Так, наприклад, показовим $є$ прийом загадки предмета, тобто концентрації уваги читача на одній деталі, що виступає відправною точкою сюжету (перстень в оповіданні «Туз і перстень», попільниця в оповіданні «Історія попільниці»). Цей прийом надає подіям деякої метафоричності, є основою притаманної романтикам таємничості, недомовленості. Подібну роль відіграє і засіб колового обрамлення (оповідання «Мамутові бивні»). Щоправда, крім виконання суто стильової функції, порівняння загибелі сількора 3 убивством мамонта Віма в первісну епоху, по-перше, підкреслює бажання автора акцентувати зв'язок часових площин, а по-друге, у даному оповіданні $є$ ще й протестом проти шаблонних художніх рішень, про що свідчить символічне звернення: «<..> та дайте ж хоч перед кінцем сеансу виплакатись флейті!» ${ }^{3}$.

Отже, настанова на заперечення усталених традицій, що знайшла своє відображення в перелічених ознаках стильової манери Ю. Яновського (неординарність героїв, пристрасність, емоційність

${ }^{3}$ Там само. С. 123. 
оповіді, загадки в сюжетах, експерименти на рівні композиції тощо), видавала романтичну природу ранньої прози митця. Творам окресленого періоду притаманні потяг до незвичайного, пошук піднесеного і яскравого в житті, суб'єктивність оцінок, задекларована художньою активністю авторського «я», що стало прогресивним виявом неоромантичних тенденцій, які письменники 20-х років XX століття, Ю. Яновський також, підхоплювали як естафету в західних колег, виявляли водночас свою індивідуальну творчу майстерність. Однак маємо зауважити, що за всієї перспективності обраного шляху в оповіданнях збірок «Мамутові бивні» та «Кров землі» спостерігається, крім стихійного відчуття власної творчої сили, деяка обмеженість мистецької вправності. Не можемо не погодитися 3 окремими представниками тогочасної критики, які зазначали низку недоліків, що деякою мірою знижують якість художнього осмислення дійсності у творах прозаїка. Передусім це спрощена подача героїв, навмисне «оголення» прийомів побудови оповіді, відсутність фабульної чіткості, надмірність ліричних відступів, недосконалість сюжетної будови, коли «прекрасно скрупульозно обробляючи окремі місця, Яновський часто-густо безпорадно метушиться коло тих ланцюгів, що їх мають зв'язувати» ${ }^{4}$, іноді невитриманість чергування епізодів тощо. Ці стильові огріхи письменника-початківця дещо ускладнюють усвідомлене розуміння правди українського пореволюційного життя з усіма його суперечливими конфліктами, але повною мірою реалізують інше завдання. Ще О. Білецький указував на те, що художні пошуки в межах ранньої творчості Ю. Яновського спрямовані передусім на деструкцію старих форм, їхня мета - «надати деякої новини читачевому сприйманню» ${ }^{5}$, а отже, ці оригінальні спроби, овіяні запальною романтикою, обов'язково мають посісти належне місце в історії української літератури XX століття.

\section{2. Стильова оригінальність роману «Майстер корабля»}

Ніби у відповідь критиці, у першій збірці 1925 року Ю. Яновський писав: «А пройде час, а зігнуться мої юнацькі плечі, і перше срібло на голові неминуче надійде - я буду суворим майстром. Я не випущу тоді блукати між рядками зайвого слова, я не дам бачити будування своїх будинків. Моє перо холодно ліпитиме рядки, і книжка, як дім, чекатиме недовговічного хазяїна - чужої думки» ${ }^{6}$. Через три роки після

\footnotetext{
${ }^{4}$ Якубовський Ф. Рецензія на збірку Ю. Яновського «Мамутові бивні». Життя і революиія. 1925. № 9. С. 102.

${ }^{5}$ Білецький О. Проза взагалі й наша проза 1925 року. Літературно-критичні статті. Київ : Дніпро, 1990. С. 82.

${ }^{6}$ Яновський Ю. Твори : у 5-ти т. Київ : Дніпро, 1983. Т. 1. С. 64-65.
} 
написаного з'явиться перша романна форма письменника - «Майстер корабля», - що як оповідача пропонує літню людину, яка прожила довгий вік і ділиться своїми спогадами. Однак на цьому факті перегук попередніх міркувань та нового твору вичерпується, бо в розповіді старого ветерана кіномистецтва виразно чується голос молодого романтика Ю. Яновського, який сміливо продовжив обраний шлях пошуку нових форм у літературі, крізь призму юнацького захоплення своєю епохою оспівав енергію творчої праці та безнастанної допитливості. Критика одразу відгукнулась на це самобутне явище тогочасної літератури, щоправда, оцінила його з помітною обережністю (що загалом закономірно для визначеного періоду). Зокрема, у своїй рецензії М. Доленго відзначав, що роман «<...> треба привітати і за певну довершеність виконання, i за мажорний його тон, хоч і важко його визнати за твір, остаточно приналежний до літератури пролетарської» ${ }^{7}$.

Справді, роман «Майстер корабля» не входив до числа заідеологізованих художніх творів, знівечених непорушним каноном соцреалізму. Він не вписувався в рамки традиції тогочасної української прози і був явищем цілком неординарним. Поставивши перед собою мету відтворити героїчний гомін доби, на композиційному рівні Ю. Яновський відмовився від лінійної оповіді, натомість удало поєднав мемуарне обрамлення роману, прийом перемежування часових площин та численні вставні новели (листи, екзотичні оповіді, філософські роздуми тощо). Така авторська позиція залежала насамперед від обраного ним романтичного стилю відтворення життя, що вимагав від письменника всебічного охоплення подій.

Як і в ранніх оповіданнях, домінантою роману Ю. Яновського залишається відмежування від усталеного канону, відкидання будьякого уніфікаторства в художній творчості. Поклавши в основу «Майстра корабля» показ творчого процесу, письменник мав намір висвітлити його 3 усіх боків, надати оповіді масштабності й поліфонізму звучання, щоб у фіналі твору об'єднати в непорушне ціле людину як творчу особистість і людину як носія кращих моральних чеснот. Саме із цією метою використовується мемуарна форма роману. Водночас події нібито далеких від сучасності років сприймаються як дійсність, що стала для головного героя То-Ма-Кі єдино реальною, наповнила його життя сенсом, бо поєднала такі суттєві складові частини людського існування, як молодість, кохання, творчість. Цей типовий для романтика прийом - перемежування часових площин - виконує подвійну функцію. 3 одного боку, молодість героя дає авторові можливість подати події його особистої та творчої

7 Доленго М. Рецензія на роман «Майстер корабля» Ю. Яновського. Червоний шиях. 1929. № 2. С. 165. 
біографії в обрамленні піднесено пафосу, використати всі можливі відтінки емоцій, не стримувати політ своєї фантазії; 3 іншого зауваження про те, що описані події пропущені крізь досвід літньої людини, поціновані іï мудрістю, робить основну ідею роману більш вагомою, глибоко усвідомленою. Для виконання письменником поставленого завдання це органічно й необхідно.

У перших шести розділах Ю. Яновський за допомогою відтворення розмов, спогадів, нібито незначних зауважень знайомить читача з усіма героями і натякає на те, що стане основним конфліктним вузлом, сценарій. Отже, до кінця шостого розділу маємо оригінально подану передісторію. Переплетення творчих і суто особистих клопотів людей, що були зайняті кіносправою, демонструють картину перших кроків української кінематографії, подають майстерно виписані портрети представників вітчизняної культури. «Майстер корабля» відзначається певною фактографічністю оповіді, тому деякі оцінки, як, наприклад, судження М. Ушакова: «<... якщо Яновський писав у ті часи про кінофабрику, бульвар, готель, то це була не Одеська кінофабрика на Французькому бульварі і не «Лондонський» готель, а місто з великої літери, як його і позначає автор, - місто примарне і непевне, лише видиво міста, і головна його жителька Тайах була тільки прекрасним привидом, втіленням закоханості, а навколо неї рухались інші місячні персонажі 3 великої літери, привиди кінематографістів і моряків, і все це закохане i глухоніме, не мавши характерів, губилося десь у туманній утопії», видаються досить суб'єктивними. Та все ж наведений вислів, на наш погляд, наштовхує на правильне розуміння стильової домінанти роману. Могутній романтичний струмінь робить «Майстра корабля» далекий від звичайного літопису доби. Роман цінний передусім своїм узагальнюючим підтекстом. Його образно-метафоричний лад наштовхує читача на думку, що творче натхнення, турбота про майбуття становлять собою сенс життя кожної людини, яка прагне перетворити свою державу на країну вільної праці та вільних у своїй самореалізації особистостей. Тому в мемуарах То-Ма-Кі так багато роздумів про велике покликання людини-трудівника, про красу i правду творчості, про необхідність збереження людської душі, що в оповідній структурі роману поступово переростає в символ духовності загалом. Її всебічний вияв утілюється для Ю. Яновського в поняття «культура нації», що стала єдиною нареченою для наділеного життєвою мудрістю оповідача: «Сімдесят років стою я на землі, пройшли переді мною покоління чужих і рідних людей, і всім я з гордістю дивився у вічі, боронячи життя і честь моєї нареченої. Її коси, як струмені, розлилися по землі, іiі руки, як благословення, лягли на поля, iï серце палає, як серце землі, посилаючи

${ }^{8}$ Островський Г. Все, що лишилось <...>. Вітчизна. 1993. № 3-4. С. 106. 
жагучу кров на нові й нові шляхи. Для неї я був сміливий і впертий, заради неї я хотів бути в першій лаві бійців - бійців за ії розквітання. Для неї я полюбив море, поставив на іiї гербі якір, залізний важкий якір, що його приймають усі моря світу, і колишеться над ним могутній корабель. Культура нації- звуть іiі» ${ }^{9}$.

Цей монолог, максимально насичений романтичним пафосом відданості своїй країні, своєму народові, визначив основні мотиви поведінки i взаємин усіх персонажів «Майстра корабля». Їхнім життєвим кредо, що вичитується 3 кожної сторінки роману, стала натхненна праця, повна самовіддача обраній справі. «Це бойова романтика захоплення тим прекрасним рухом життя, коли ти «гребеш і гребеш, вигрібаючись проти течії, проти всього на світі пливеш

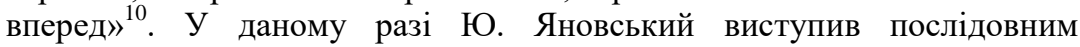
представником активного романтизму, бо зміг відтворити поступальний рух своєї епохи вперед, заперечував все негативне та відверто шкідливе. Він наповнив твір глибокою символікою на рівні висвітлення основної ідеї та в межах інтерпретації світоглядних переконань героїв, що в підсумку дозволило письменнику майстерно передати атмосферу щоденного героїзму звичайних людей.

Можемо стверджувати, що i написання сценарію, i побудова корабля для майбутнього фільму в романі $є$ добре продуманими художніми прийомами, що своєрідним способом транслюють читачеві авторські роздуми про долю країни. Якою їй бути? Який шлях обрати? На ці запитання дають образну відповідь і То-Ма-Кi, i Сев, і Богдан, і Професор, які використовують мотив будівництва корабля. На переконання письменника, кожна людина повинна зробити свій внесок у загальну справу, віддати ӥй знання і досвід, щоб потім мати право користуватися результатами спільної діяльності. Саме так підходять герої роману до справи побудови корабля (за сюжетом), а отже, і до справи побудови нової держави (на загальному ідейному рівні). Свідченням цього можуть слугувати міркування мудрого Професора про те, що «людина - натура творча, людині треба, щоб ії робота залишалася після неї самої жити. Тоді людина працюватиме так, як співає» ${ }^{11}$. Ця життєствердна романтика підсилюється тим фактом, що герої «Майстра корабля» не знають вагань і сумнівів, вони чітко уявляють собі майбутнє, яке 3 винятковим ентузіазмом почали будувати: «Я бачу, як повиростали заводи і фабрики. Розмножилися

${ }^{9}$ Яновський Ю. Твори : у 5-ти т. Київ : Дніпро, 1983. Т. 2. С. 29-30.

10 Костюк Г. Романтика життя: роман «Майстер корабля». У світлі iдей і образів. Вибране. Критичні та історико-літературні роздуми 1930-1080. Київ : Сучасність, 1983. С. 174.

${ }^{11}$ Яновський Ю. Твори : у 5-ти т. Київ : Дніпро, 1983. Т. 2. С. 119. 
дороги. Вода ріки віддає свої мільйони сил. Коло плугів працює веселий народ. Сонце смажить радісні обличчя. Армії дітей пищать по садках, голосять, співають, сьорбають носятами, плачуть, сміються, жують землю і поїдають трави» ${ }^{12}$. А отже, другою, поряд 3 уславленням творчої особистості, домінантою роману «Майстер корабля» $є$ ідея всеохоплюючої любові до рідної землі.

На наш погляд, у творі ми можемо знайти своєрідний образний відгук на запитання М. Хвильового «Камо грядеши, Україно?». Ю. Яновський роздумує над тими шляхами, що їх обрала його держава, ставши до культурного будівництва в перше повоєнне десятиріччя. Показово, що висвітлення проблеми найближчого майбуття України для письменника нерозривно пов'язане 3 роздумами про високе покликання людини-трудівника, про творчу наснагу та націленість на боротьбу 3 патріархальною відсталістю в людській свідомості. Напоєний молодістю оптимістичний настрій, нестримне прагнення швидкого оновлення знаходять своє втілення в метафоричному порівнянні перспектив нової держави 3 морською стихією: «Тому я й люблю море, що на ньому кожна дорога нова і кожне місце - дорога» ${ }^{13}$. Із запальністю романтика Ю. Яновський постійно демонструє захоплення прекрасним рухом життя. Саме ця беззастережна віра у свою країну дала право його героєві, а отже, і самому авторові, у складний для України час на запитання «якою їй бути?» дати однозначно обнадійливу відповідь.

Окреслені переконання письменника підсилюються вітаїстичним духом любові «до найпрекраснішого (о, повірте мені), що я знав у світі, - до Життя» ${ }^{14}$. Як філософія звеличення краси людського існування сприймається будь-яка думка в романі - від поромантичному натхненного оспівування творчої праці й духовності до глобальних роздумів про шляхи розвитку культури і нації. Тому романтика Ю. Яновського в контексті роману «Майстер корабля» сприймається як життєствердна, вольова, насичена вірою в непереможну міць сильної людини, а отже, і сильної нації. У цьому, на нашу думку, полягає потужний громадянський пафос твору.

Ознак романтичного символу, що повною мірою передає ідею творчих пошуків, розкриває таїну взаємозв'зку теперішнього і майбутнього, утілює нестримність поривів людської душі, у Ю. Яновського набуває образ моря. «Майстер корабля» - єдиний твір митця, щедро насичений мариністичним колоритом. Морська стихія в романі асоціюється з високими життєвими устремліннями його героїв.

\footnotetext{
12 Там само. С. 161.

13 Там само. С. 27.

${ }^{14}$ Там само. С. 11.
} 
Море стає свідком усіх подій, воно випробовує волю і міць людини, $\epsilon$ мірилом прекрасного і ганебного. Показово, що особлива образність роману наводила декого з його дослідників на думку про безпосередній вплив на індивідуальний стиль письменника романтиків-мариністів О. Гріна, Дж. Конрада й інших. Появі таких тлумачень могло сприяти зізнання самого Ю. Яновського: «Любив я англійців та американців. Їхні твори правили мені за вікно до великого світу. Тоді я захопився морем, не побачивши його» ${ }^{15}$. Однак, як зазначає М. Ласло-Куцюк, український прозаїк запозичує від Дж. Конрада в основному пригодницькі елементи й екзотичну декорацію, що має на меті розбудити фантазію читача. Що ж до ідейного навантаження, то морські простори Дж. Конрада - це символ трагічної самотності людини посеред стихії розбурханого всесвіту, тоді як у Ю. Яновського образ моря, завжди мінливого, лише підкреслює невпокоєність поривань персонажів роману, їхній активний щоденний героїзм.

3 іншого боку, мариністичний колорит «Майстра корабля» став основою екзотичності твору. Це насамперед розповіді Богдана про його пригоди, що тісно переплелися 3 темою любові до рідного краю. Композиційно вони мають вигляд окремих новел, уведених автором у твір як матеріал до майбутнього сценарію, на перший погляд, крім цього, не мають нічого спільного з подіями, що відбуваються в романі. Але на ідейному рівні лейтмотивом усіх розповідей про неймовірні мандрівки моряка стає жагуче бажання будь-що жити, навіть більше, жити на рідній землі. Отже, вітаїстична ідея любові до життя в поєднанні 3 національним самоусвідомленням людини ще раз підкреслює романтичну орієнтованість «Майстра корабля».

Деталізуючи тлумачення особливостей екзотичності твору Ю. Яновського, варто наголосити, що вона не лише увібрала в себе яскраві морські пейзажі та цікаві пригоди, а й стала основою авторської характеристики окремих персонажів. Як уже зазначалось, романтикою морів овіяний образ Богдана. Його незвичайна поява в романі, події, в епіцентр яких він потрапляє, створюють атмосферу таємничості, загадковості. Цей ореол не зникає навіть під час більш близького знайомства. Прозаїк наділяє героя рисами людини, що прагне повноти життя, створює особистість водночас сильну, загартовану морськими вітрами, здатну на відчайдушні вчинки i чулу, 3 ніжною душею, віддану друзям i морю. Характеризуючи Богдана устами сина То-Ма-Кі, Ю. Яновський зазначає, що «<... це неймовірний оптиміст. Він належить до тих людей, з якими всі одвічні питання спрощуються до розмірів однієї фрази. Народження чи смерть вони сприймають так

15 Лист Ю. Яновського до М. Хвильового. Літературний ярмарок. 1929. № 9. C. 11. 
примітивно, що це зовсім не стає для людини на перше місце і не затуляє бадьорості й радості. За такими людьми мимоволі йдуть. 3 ними дуже легко жити. Вони сприймають життя в цілому, в нещасті знаходять радість, у болі - чують натхнення, в страхові - знають сміх. Ïх натовп висуває наперед. Вони - співаки, що знають силу пісень i співають їx у такт ході» ${ }^{16}$. Така характеристика неординарного персонажа, на наш погляд, $є$ суголосною визначенню неоромантизму, запропонованого Лесею Українкою: «Новоромантизм прагне вивільнити особистість у натовпі, розширити іiі права, дати їй можливість знаходити собі подібних чи, якщо вона виняткова і при цьому активна, дати ій змогу підносити до свого рівня інших, а не понижуватись до їхнього рівня, не бути в альтернативі вічної моральної самотності чи моральної казарми» ${ }^{17}$. Тому й не дивно, що, керуючись художніми принципами неоромантизму, Ю. Яновський саме 3 допомогою образу Богдана вирішує проблему «любовного трикутника», поєднавши цього героя з не менш загадковою і сильною особистістю - Тайах.

Як і Богдан, вона теж раптово вривається в життя персонажів, входить до нього повною нестямної жаги, спокусливою єгипетською царицею, чиє ім'я носить, відразу стверджує себе як жінка, якою керують дві пристрасті - кохання і незламна воля. Під час оповіді читач неодноразово отримує можливість переконатися, що перше враження не оманливе. Образ героїні поглиблюється іноді через характеристику інших дійових осіб, іноді за допомогою самоаналізу, демонструє водночас пристрасність і холодну розважливість. Колись зазнавши жорстоких днів зневіри, на момент оповіді Тайах відроджується до життя. Вона тонка й емоційна натура, ненавидить фальш і вперто шукає омріяний ідеал серед часом непривабливих буднів. Уважаємо, що найбільш виразно цю жінку характеризує її лист із Мілана, у якому сила почуттів бринить на найвищій ноті: «Листа 3 Мілана вона написала так гаряче, як кинулася б в обійми і як загубила б свідомість. Листа цього вигадати не можна. Тяжко придумати так, як складає раптом безліч узорів життя. Таких листів не пише жінка двох за свій вік. Але, написавши одного, летить, як бджола, на далеку пахучу квітку» ${ }^{18}$.

Закохуючи Сева і То-Ма-Кі в неординарну балерину, Ю. Яновський водночас робить їх деякою мірою творцями жіночого «я». Своїм щирим ставленням юнаки викликали 3 надр таємничої душі ті струмені, що віднині будуть скеровувати їі життя. Однак у порівнянні з чоловіками

\footnotetext{
${ }^{16}$ Яновський Ю. Твори : у 5-ти т. Київ : Дніпро, 1983. Т. 2. С. 143.

17 Леся Українка. Твори : у 12-ти т. Київ, 1977. Т. 8. С. 236-237.

18 Яновський Ю. Твори : у 5-ти т. Київ : Дніпро, 1983. Т. 2. С. 143.
} 
Тайах видається значно сильнішою в романтичному прагненні ідеалу, цей образ сприймається дещо відірваним від реальності, розрахованим на максимальний ефект. Тому за логікою романтичного твору вона й тягнеться до собі подібного. Чи не найкраще складний і суперечливий характер екзальтованої балерини відчуває Професор: «Одначе вас не задовольнить жоден мрійник і романтик. Вам треба сильної руки, пошерхлої руки моряка i його посолених вуст із запахом горілки $\mathrm{i}$ міцного матроського тютюну» ${ }^{19}$. Водночас автор далекий від думки таким спостереженням принизити силу почуттів Сева i To-Ma-Ki. Навпаки, їхня небуденність виявляється в тому, щоб бути «мудрішими за себе». У двобої між коханням і дружбою перемагає остання, і цей факт звеличує героїв, бо письменник-романтик ставить чесну і безкорисливу дружбу в один ряд із молодістю і творчим натхненням.

Дещо осібно в романі «Майстер корабля» стоїть образ Професора. На наш погляд, він $є$ символічним утіленням людської мудрості. У його монологи й поодинокі висловлювання Ю. Яновський майстерно вмонтував власні оцінки подій та вчинків героїв. Здебільшого це ліричні відступи, у яких звучать філософські узагальнення, створені на основі життєвого досвіду та суголосні поривам відкритого світу людського серця. Їхньою основною ознакою $є$ емоційність, навіть пісенність. Прикладом можуть слугувати записи в корабельному журналі майбутнього брига, де на перший погляд прозаїчні речі перетворюються ледь не на симфонію творчості. Символічним $\epsilon$ й подарунок Професора (Будда), що став ключем до розуміння провідної ідеї роману. Усередині статуетки крилося те найцінніше, що $\epsilon$ в житті кожної людини, хоча часто залишається недооціненим: зернятка рису - праця, їжа і продовження життя; трісочки, $з$ допомогою яких можна здобути вогонь; клаптик паперу - молитва.

I все ж головним героєм «Майстра корабля» вважаємо не матроса, не балерину, не Професора і навіть не То-Ма-Кі. Домінантою роману $\epsilon$ творчість. Натхненні описи наполегливої праці, щире захоплення людською майстерністю, умінням увіковічнити прекрасне виливаються у схвильований ліричний відступ - гімн рукам трудівника, що для Ю. Яновського перетворились на величний символ: «Дві людські руки вкупі - це кільце, за яке, ухопившися, можна зрушити землю» ${ }^{20}$. За такої інтерпретації символічною видається і назва твору. «Майстер корабля»вирізьблена $з$ дерева фігура, що кріпиться під бушпритом брига і веде його через морські простори, - на наш погляд, уособлює душу митця, його талант, усе те, що забезпечує безсмертя витворам мистецтва.

\footnotetext{
${ }^{19}$ Там само. С. 129.

${ }^{20}$ Там само. С. 137.
} 
Багатошарове просторово-часове компонування художнього матеріалу письменник завершує вітаїстичним акордом, що ввібрав у себе ідею нескінченності життя: «Під моїми парусами виросли молоді кораблі - сини», - підсумовує головний герой роману. У них бринить гаряча кров молодості, вони прагнуть завжди відчувати на щоках вітер шляхів, іти вперед, бо людині не властиво стояти на місці. I, коли дивиться на молоде покоління, старий Товариш Майстер Кіно ніби знову відроджується для нових звершень.

Отже, у романі «Майстер корабля» Ю. Яновський посилив притаманну його творчій особистості поетичну окриленість. Щоправда, на відміну від ранніх оповідань, автор прагне дотриматись обіцянки «бути суворим майстром». За спостереженням Г. Костюка, лірика роману значно глибша, філософія складніша, більш витончена культура слова. Однак перевантаження задуму різними побічними ефектами дещо ускладнює читацьке сприйняття твору. Крім того, у романі «Майстер корабля» усе ще трапляються невмотивовані епізоди, часом письменник переходить від ліро-епічної манери викладу до нарочитої описовості, іноді можемо спостерігати очевидний відхід від романтичного стилю. Та попри перелічені моменти, роман «Майстер корабля» залишається твором, художня цінність якого і на наш сучасний смак ані трохи не зменшилась. Його життєствердний пафос засвідчив, що на ранніх етапах творчості Ю. Яновський упевнено йшов шляхом формування нової української прози, порушував важливі проблеми й водночас видозмінював традиційну літературу суголосно власним романтичним уявленням про свій час і людей своєї буремної доби.

\section{ВИСНОВКИ}

У 20-х роках ХХ століття романтичний стиль посідав досить помітне місце у творчості нової генерації українських письменників. Пристрасне бажання виявити в людській душі благородний порив до краси і гармонії, передати поетичним словом той піднесений настрій людини, завдяки якому світ постійно вдосконалюється, націленість на боротьбу з буденщиною, на пошуки найвищого сенсу життя надихали молодих митців на сміливі художні експерименти. Тож закономірно, що саме цей період вітчизняного літературного процесу став водночас i найбільш полемічним щодо проблеми інтерпретації романтичної естетики в нових культурно-історичних реаліях. Поштовхом до такої дискусії послугував, серед іншого, і досить помітний дебют Ю. Яновського. У суперечках щодо його творчості та місця романтизму в тогочасній літературі загалом взяли участь найавторитетніші критики. Тут не бракувало і цікавих спостережень, і полемічних крайнощів. Однак час підтвердив позицію тих літературознавців, які сприйняли творчість молодого неоромантика як оригінальне й перспективне явище. 
Ранні новели та повісті Ю. Яновського відзначалися пристрасністю, емоційністю, загадковістю, несподіваними прийомами і сюжетними ситуаціями, перебували в тісному зв'язку з романтичним уявленням автора про свою епоху суспільних перетворень. Основними стильовими характеристиками збірок «Мамутові бивні» та «Кров землі» стали активність героїв у досягненні поставленої мети, їхній внутрішній героїзм, що виявлявся в найбільш напружені моменти життя, піднесеність сповідуваних ідеалів. Крім того, заперечення шаблонності простежувалось і на рівні форми оповідань. Письменник широко використовував засоби деструкції, техніку кіномонтажу, акцентував увагу читача на окремих деталях, уводив у твори елементи загадок тощо. Така своєрідність авторської інтерпретації дійсності в супроводі запальної романтики на рівні емоційних домінант чітко визначала романтичну орієнтованість «малої прози» митця.

Обраний шлях Ю. Яновський продовжив у романі «Майстер корабля», що своєю стильовою спрямованістю затвердив активний романтизм як провідний художній метод письменника. В основі роману лежить показ творчого процесу, який поєднав у собі дійсність та ідеал. Автор роздумує над тими шляхами, які обрала Україна, ставши до культурного будівництва в перші повоєнні роки. У центрі уваги письменника - високе покликання людини-трудівника на землі, творча наснага, ентузіазм, прагнення побороти відсталість та патріархальщину в людській свідомості. Для досягнення поставленої мети автор використовує багатий спектр романтичних прийомів, зокрема глибоку символіку, екзотичність, метафоричність, багатошарове просторовочасове компонування матеріалу, використання ліричних відступів, філософських узагальнень тощо. У романі «Майстер корабля» діють сильні, вольові герої, чиї щоденні турботи овіяні патетикою молодості, кохання та творчої наснаги. 3 допомогою перелічених засобів і досягається головна мета твору - показ гармонійного поєднання дійсності й ідеалу у процесі творчості, - що стала домінантою активного романтизму як специфічного стильового утворення української літератури 20 -х років XX століття.

\section{АНОТАЦІЯ}

Об'єктом дослідження у запропонованій статті стали зразки ранньої прози Ю. Яновського, зокрема збірки оповідань «Мамутові бивні», «Кров землі» та роман «Майстер корабля». Авторка поставила мету дослідити стильову оригінальність означених творів. У процесі аналізу вдалося з'ясувати, що на початковому етапі літературної діяльності Ю. Яновський дотримувався естетичних настанов неоромантизму в його українському інваріанті. Серед основних стилетворчих засобів були виявлені ідеалізація сильної особистості, віра в ідеал, 
використання принципу контрасту, символіки, елементів екзотичності тощо. Однак, на відміну від класичних романтиків, український письменник не протиставляв дійсність і мрію. Його ідеали були закорінені в реалії побудови нової держави. У ранніх оповіданнях Ю. Яновський звеличував людей, вірних обов'язку, здатних на піднесені почуття. Ідейною домінантою роману «Майстер корабля» стало авторське розуміння самовідданої творчої праці як рушійної сили на шляху до реалізації поставлених завдань.

\section{ЛIТЕРАТУРА}

1. 20-ті роки: літературні дискусії, полеміки : літературно-критичні статті / упор. В. Дончик. Київ : Дніпро, 1991. 366 с.

2. Білецький О. Літературно-критичні статті. Київ : Дніпро, $1990.254 \mathrm{c}$.

3. Доленго М. Рецензія на роман «Майстер корабля» Ю. Яновського. Червоний шляхх. 1929. № 2. С. 160-166.

4. Костюк Г. У світі ідей і образів. Вибране. Критичні та істориколітературні роздуми 1930-1980. Київ : Сучасність, 1983. 457 с.

5. Ласло-Куцюк М. «Вікно до великого світу» Юрія Яновського. Шукання форми. Бухарест : Критеріон, 1980. С. 165-190.

6. Лист Ю. Яновського до М. Хвильового. Літературний ярмарок. 1929. № 9. С. 11.

7. Могилянський М. Проза Ю. Яновського. Червоний шлях. 1925. № 10. С. 212-219.

8. Павличко С. Дискурс модернізму в українській літературі. Київ : Либідь, 1997. 357 с.

9. Леся Українка. Твори : у 12-ти т. Київ, 1977. Т. 8. 316 с.

10. Якубовський Ф. Рецензія на збірку Ю. Яновського «Мамутові бивні». Життя і революиія. 1925. № 9. С. 101-103.

11. Якубський Б. Юрій Яновський та його «Майстер корабля». Життя і революичя. 1929. № 3. С. 84-99.

12. Яновський Ю. Твори : у 5-ти т. Київ : Дніпро, 1983. Т. 1, 2.

\section{Information about the author:} Savchenko Z. V.,

Candidate of Philological Sciences, Associate Professor at the Department of Russian Language, Foreign Literature and Methods of Teaching Sumy State Pedagogical University named after A. S. Makarenko 87, Romenska str., Sumy, 40002, Ukraine 